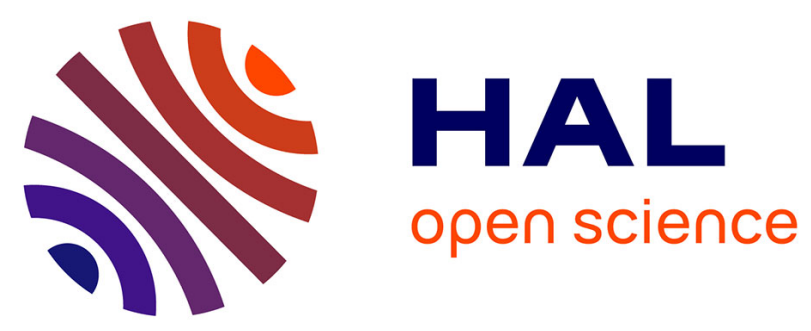

\title{
Kinematics of the East African Rift from GPS and earthquake slip vector data
}

\author{
E. Calais, C.J. Ebinger, C. Hartnady, J.-M. Nocquet
}

\section{To cite this version:}

E. Calais, C.J. Ebinger, C. Hartnady, J.-M. Nocquet. Kinematics of the East African Rift from GPS and earthquake slip vector data. The Geological Society, London, Special Publications, 2006, 259, pp.9-22. 10.1144/GSL.SP.2006.259.01.03 . hal-00407586

\section{HAL Id: hal-00407586 \\ https://hal.science/hal-00407586}

Submitted on 26 Jul 2019

HAL is a multi-disciplinary open access archive for the deposit and dissemination of scientific research documents, whether they are published or not. The documents may come from teaching and research institutions in France or abroad, or from public or private research centers.
L'archive ouverte pluridisciplinaire HAL, est destinée au dépôt et à la diffusion de documents scientifiques de niveau recherche, publiés ou non, émanant des établissements d'enseignement et de recherche français ou étrangers, des laboratoires publics ou privés. 


\title{
Kinematics of the East African Rift from GPS and earthquake slip vector data
}

\author{
E. CALAIS ${ }^{1}$, C. EBINGER ${ }^{2}$, C. HARTNADY ${ }^{3}$, \& J.M. NOCQUET ${ }^{4}$ \\ ${ }^{1}$ Purdue University, Department of Earth and Atmospheric Sciences, West Lafayette, Indiana, \\ USA (e-mail: ecalais@purdue.edu) \\ ${ }^{2}$ Department of Geology, Royal Holloway, University of London, Egham, UK \\ ${ }^{3}$ Umvoto Africa (Pty) Ltd, PO Box 61, Muizenberg, South Africa 7950 \\ ${ }^{4}$ CNRS, UMR6526 Géosciences Azur, Valbonne, France
}

\begin{abstract}
Although the East African Rift (EAR) System is often cited as the archetype for models of continental rifting and break-up, its present-day kinematics remains poorly constrained. We show that the currently available GPS and earthquake slip vector data are consistent with (1) a present-day Nubia-Somalia Euler pole located between the southern tip of Africa and the Southwest Indian ridge and (2) the existence of a distinct microplate (Victoria) between the Eastern and Western rifts, rotating counter-clockwise with respect to Nubia. Geodetic and geological data also suggest the existence of a (Rovuma) microplate between the Malawi rift and the Davie ridge, possibly rotating clockwise with respect to Nubia. The data indicate that the EAR comprises at least two rigid lithospheric blocks bounded by narrow belts of seismicity ( $<50 \mathrm{~km}$ wide) marking localized deformation rather than a wide zone of quasi-continuous, pervasive deformation. On the basis of this new kinematic model and mantle flow directions interpreted from seismic anisotropy measurements, we propose that regional asthenospheric upwelling and locally focused mantle flow may influence continental deformation in East Africa.
\end{abstract}

The East African Rift (EAR), a $5000 \mathrm{~km}$-long series of fault-bounded depressions straddling east Africa in a roughly north-south direction, marks the divergent boundary between two major tectonic plates, Somalia and Nubia (Fig. 1). Although the EAR is often cited as a modern archetype for rifting and continental break-up and a Cenozoic continental flood basalt province, its current kinematics is still poorly understood and quantified, owing in part to its tremendous extent and inaccessibility.

Jestin et al. (1994) were among the first to quantify the kinematics of the EAR by estimating a $3 \mathrm{Ma}$ average Nubia-Somalia angular velocity. Using Arabia-Nubia and Arabia-Somalia relative motions determined from marine geophysical data in the Red Sea and Gulf of Aden, they find a Nubia-Somalia Euler pole south of the Southwest Indian Ridge (Fig. 1). Their result differs significantly from that of Chu \& Gordon (1999), who estimate a $3 \mathrm{Ma}$ average Nubia-Somalia angular velocity from marine geophysical data along the Southwest Indian ridge and the AntarcticaSomalia and Antarctica-Nubia plate closure circuit (Fig. 1). More recently, direct estimates of the Nubia-Somalia plate motion have been made possible thanks to a limited number of permanent Global Positioning System (GPS) stations on both plates. For instance, Sella et al. (2002) used two GPS sites on the Somalian plate and four on the Nubian plate, while Fernandes et al. (2004) used three GPS sites on the Somalian plate and 11 on the Nubian plate and longer data time series. Again, these two GPS estimates of the NubiaSomalia angular velocity differ significantly from each other, as well as from previous results derived from oceanic data (Fig. 1).

In addition to far-field plate motions, the kinematics of the EAR itself remains an open question. Some authors have proposed that the EAR consists of a mosaic of rigid lithospheric blocks bounded by localized deformation within narrow seismically and volcanically active rift valleys (e.g. Ebinger 1989; Hartnady 2002). Others favour a broad deformation zone (e.g. Gordon 1998) implicit in models that assume a weak mantle lithosphere beneath continents (e.g. Jackson 2002). But the distribution of strain across and along the EAR is currently unknown and no quantitative kinematic data are presently available for that plate boundary. In this paper, we use an updated GPS and earthquake slip vector data set to estimate the Somalia-Nubia angular velocity and propose a first-order kinematic model for present-day deformation in the EAR. 


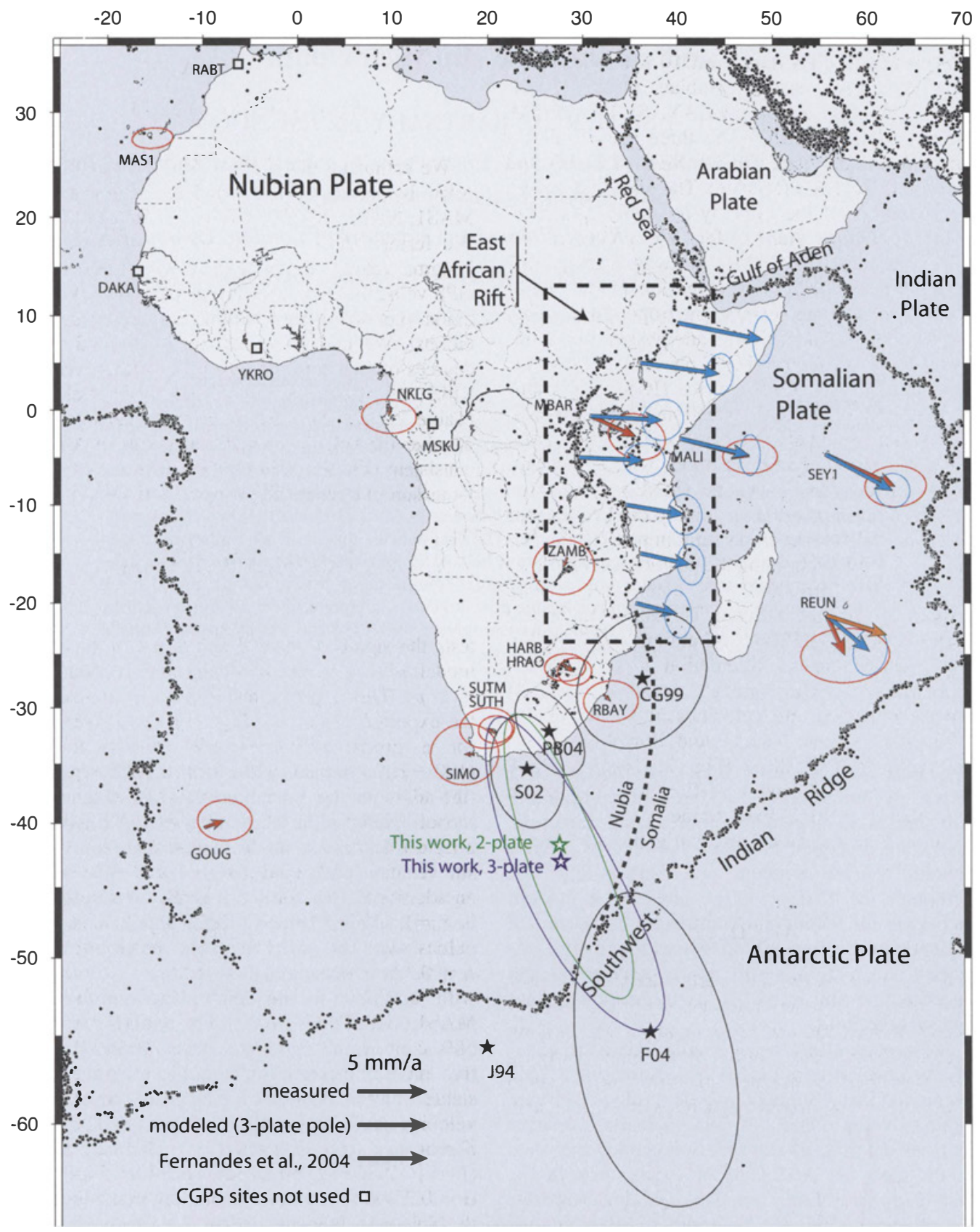

Fig. 1. GPS sites used in this study. Dots show seismicity (NEIC catalog). Stars are Euler poles for Somalia-Nubia relative motion with associated 1 -sigma error ellipse. S02 = Sella et al. 2002; PB04 = Prawirodirdjo \& Bock 2004; F04 = Fernandes et al. 2004; CG99 = Chu \& Gordon 1999; J94 = Jestin et al. 1994 . This work 2-plate= twoplate inversion using GPS velocities at MALI, REUN and SEY1 + nine earthquake slip vectors along the Main Ethiopian Rift. This work 3-plate = three-plate inversion using GPS velocities at MBAR, MALI, REUN, SEY 1 and 47 earthquake slip vectors along the East African Rift (see Figure 2 and Table 1). Curved dashed line shows the NubiaSomalia plate boundary in the SW Indian Ocean proposed by Lemaux et al. 2002. 


\section{GPS data}

We processed GPS data from 10 permanent GPS sites operating on the Nubian plate (MAS1, GOUG, NKLG, ZAMB, RBAY, SUTH, SUTM, HRAO, HARB, SIMO), the three sites available on the Somalian plate (MALI, SEY1, REUN), and one site in the EAR (MBAR). The results presented here include all the publicly available data from August 1998 to April 2005. We processed the GPS data using the GAMIT software version 10.2 (King \& Bock 2005). We solved for station coordinates, satellite state vectors, one tropospheric delay every four hours at each site, and phase ambiguities using double-differenced GPS phase measurements, with International GPS Service (IGS) final orbits and International Earth Rotation Service (IERS) Earth orientation parameters relaxed. We then combined our regional daily solutions with global Solution Independent Exchange (SINEX) files from the IGS daily processing routinely done at Scripps Institution of Oceanography and imposed the reference frame by minimizing the position deviations of 38 globally distributed IGS core stations with respect to the International Terrestrial Reference Frame 2000 (ITRF2000; Altamimi et al. 2002), while estimating an orientation and translation transformation. Our primary result consists of precise positions and velocities at 14 continuous GPS sites on the Nubian and Somalian plates, expressed in ITRF2000 (Fig. 2; Table 1). In a second step, explained hereafter, we rotate these velocities in a Nubia-fixed frame.

GPS velocities, in a Cartesian geocentric frame, can be modelled as:

$$
\vec{V}=\vec{\Omega} \times \vec{P}
$$

where $P(x, y, z)$ is the unit vector defining the position of the GPS site, $V(v x, v y, v z)$ is the velocity vector at that site, and $\Omega\left(\omega_{x}, \omega_{y}, \omega_{z}\right)$ is the rotation vector defining the motion of the plate carrying the site. For a number of sites on a given plate, this cross product can be written in matrix form as:

$$
\left(\begin{array}{c}
v x_{1} \\
v y_{2} \\
v z_{3} \\
\ldots
\end{array}\right)=\left(\begin{array}{ccc}
0 & Z_{1} & -Y_{1} \\
-Z_{1} & 0 & X_{1} \\
Y_{1} & -X_{1} & 0 \\
\ldots & &
\end{array}\right)\left(\begin{array}{l}
\omega_{x} \\
\omega_{y} \\
\omega_{z}
\end{array}\right)
$$

or

$$
V=A \Omega(\Sigma)
$$

where $V$ is the vector of observations with its associated covariance matrix $\Sigma, A$ the model matrix, and $\Omega$ the vector of unknowns. The least-squares solution is then given by:

$$
\Omega=\left(A^{T} \Sigma^{-1} A\right)^{-1} A^{T} \Sigma^{-1} V
$$

We estimated the Nubia-ITRF2000 angular velocity by inverting horizontal velocities at sites MAS1, NKLG, SUTH, SUTM and GOUG (Fig. 1). We formed the data covariance matrix using the 2 -sigma velocity uncertainty ( $95 \%$ confidence) on GPS velocities and their site-by-site NS-EW correlation (i.e. we do not account for intersite correlations). We find a reduced $\chi^{2}\left(\chi^{2}\right.$ divided by the degrees of freedom) close to unity with a weighted RMS of $0.7 \mathrm{~mm} \mathrm{a}^{-1}$ for horizontal velocities (Table 2). We then use an $F$-ratio statistic to test whether the velocity at additional sites in Africa is consistent with the rigid rotation defined by the previous subset of sites. The $F$-ratio, defined by:

$$
F=\frac{\left[\chi^{2}\left(p_{1}\right)-\chi^{2}\left(p_{2}\right)\right] /\left(p_{1}-p_{2}\right)}{\chi^{2}\left(p_{2}\right) / p_{2}},
$$

tests the significance of the decrease in $\chi^{2}$ from a model with $p_{2}$ versus $p_{1}$ degrees of freedom, with $p_{1}>p_{2}$. This experimental $F$-ratio is compared to the expected value of a $F\left(p_{1}-p_{2}, p_{1}\right)$ distribution for a given risk level $\alpha \%$ (equivalent to a $(100-\alpha) \%$ confidence level) that the null hypothesis (the additional site is consistent with the rigid plate model) can be rejected. The degrees of freedom of a rigid rotation estimation is $p_{1}=2 \times N-3$ for $N$ site velocities, it becomes $p_{2}=2 \times N-3-2$ with an additional site. For site ZAMB, the $F$-test value is $F=[(8.52-7.53) /(9-7)] /[7.53 / 7]=0.4$ (using values provided in Table 1), corresponding to $\alpha=0.32$. The velocity at ZAMB is consistent with a Nubian plate model (defined by sites MAS1, NKLG, SUTH, SUTM and GOUG) at a $68 \%$ confidence level. This indicates that the relative motion between the Zambia craton and the stable Nubian plate is less than the residual velocity at $Z A M B$, or $\sim 1 \mathrm{~mm} \mathrm{a}^{-1}$. The same $F$-ratio test with sites HRAO, HARB and RBAY $(F=[(12.87-7.53) /(15-7)] /[7.53 / 7]=0.62$, $\alpha=0.25$ ) shows that these sites are consistent with the Nubian plate model defined above at a $75 \%$ confidence level. However, both HRAO and RBAY are separated from stable Nubia by the seismically active Okavango Rift in Botswana (Modisi et al. 2000) and the Senqu Seismic Belt in South Africa and Lesotho (Hartnady 1998) and may lie on a microplate separate from Nubia and Somalia (Transgariep block of Hartnady 2002). We therefore did not use them in our final NubiaITRF2000 angular velocity estimate. 

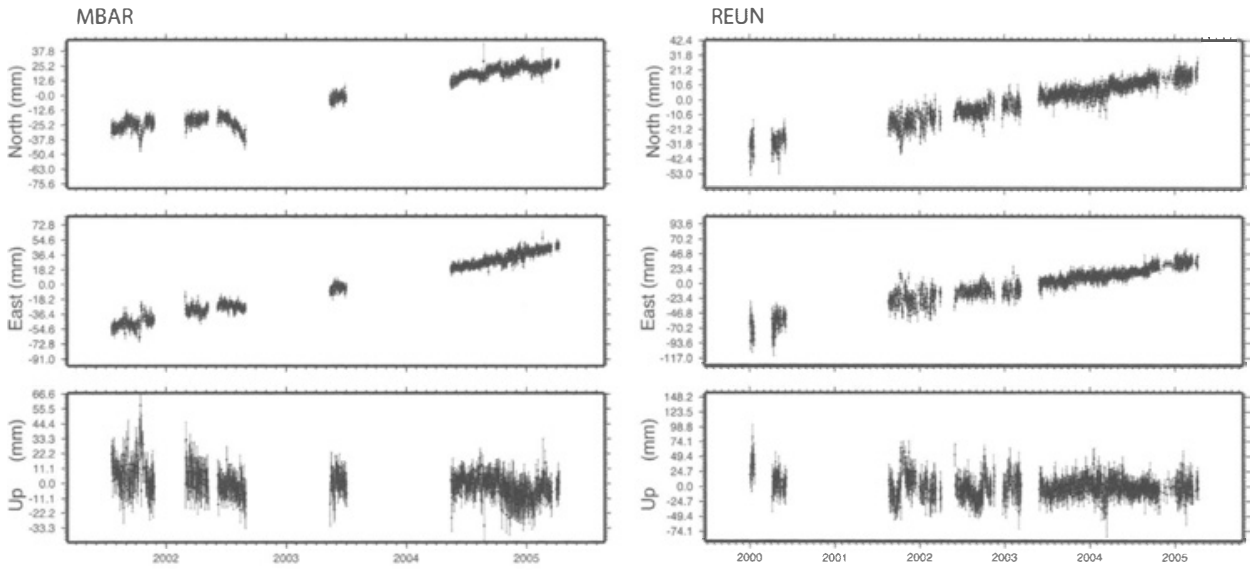

SEY
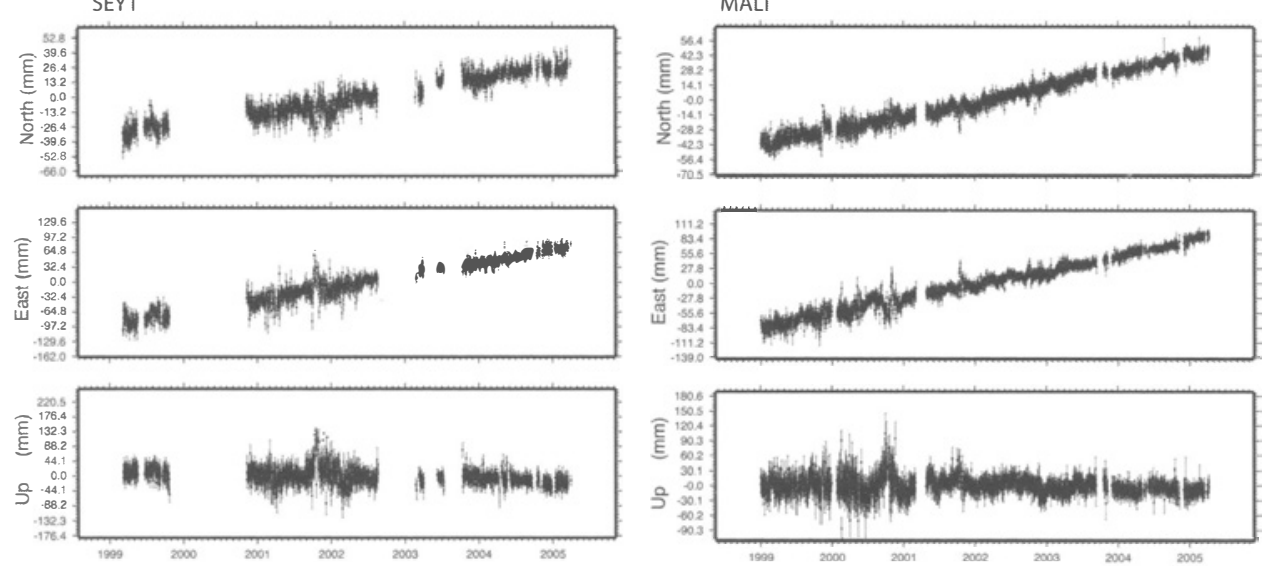

Fig. 2. Position time series for sites MBAR, REUN, MALI and SEY1, with one position per day and its associated one-sigma formal error, shown with respect to the weighted mean of the entire time series. Each component (northsouth, east-west, vertical) is shown separately.

Table 1. GPS velocities

\begin{tabular}{lrrrrrrr} 
Site & \multicolumn{1}{c}{ lon. } & lat. & $V_{\mathrm{e}}$ & $V_{\mathrm{n}}$ & $\sigma_{\mathrm{e}}$ & $\sigma_{\mathrm{n}}$ & \multicolumn{1}{c}{ Corr. } \\
GOUG & 350.12 & -40.35 & 22.3 & 17.9 & 0.8 & 0.6 & 0.033 \\
HARB & 27.71 & -25.89 & 17.7 & 17.1 & 0.6 & 0.4 & -0.014 \\
HRAO & 27.69 & -25.89 & 18.4 & 16.8 & 0.5 & 0.4 & -0.032 \\
MALI & 40.19 & -3.00 & 26.9 & 14.3 & 0.8 & 0.5 & 0.039 \\
MAS1 & 344.37 & 27.76 & 16.5 & 16.7 & 0.5 & 0.3 & -0.017 \\
MBAR & 30.74 & -0.60 & 26.1 & 16.6 & 1.0 & 0.7 & -0.006 \\
NKLG & 9.67 & 0.35 & 22.3 & 17.7 & 0.8 & 0.5 & -0.079 \\
RBAY & 32.08 & -28.80 & 16.6 & 16.3 & 0.8 & 0.6 & -0.002 \\
REUN & 55.57 & -21.21 & 17.3 & 9.6 & 1.4 & 0.8 & 0.064 \\
SEY1 & 55.48 & -4.67 & 26.2 & 10.3 & 1.0 & 0.6 & 0.087 \\
SIMO & 18.44 & -34.19 & 16.0 & 18.1 & 1.1 & 1.0 & 0.015 \\
SUTH & 20.81 & -32.38 & 16.7 & 18.2 & 0.5 & 0.4 & -0.016 \\
SUTM & 20.81 & -32.38 & 16.1 & 18.4 & 0.8 & 0.6 & 0.022 \\
ZAMB & 28.31 & -15.43 & 19.6 & 16.6 & 1.0 & 0.8 & 0.028
\end{tabular}

Velocities $\left(V, \mathrm{~mm} \mathrm{a}^{-1}\right)$ with respect to ITRF2000 and associated one standard deviation formal errors $\left(\sigma, \mathrm{mm} \mathrm{a}^{-1}\right)$ and their correlation (Corr.). 


\section{Somalia-Nubia plate motion}

Finally, we rotate the ITRF2000 velocities into a Nubia-fixed frame using the Nubia-ITRF angular velocity estimated with MASI, NKLG, SUTH, SUTM and GOUG. We use the Nubia-fixed velocities at sites MBAR, MALI, SEY1 and REUN in the following kinematic analysis. In addition to GPS velocities, we use slip vectors derived from the 53 focal mechanisms determined from body-waveform inversion by Foster \& Jackson (1998), augmented by the Harvard Centroid Moment Tensor (CMT) database (Fig. 3a). We use the same slip vectors as Foster \& Jackson (1998), who based their choice on structural framework of each epicentral region. We follow the same criteria for the additional CMT events. The joint inversion of geodetic and slip vector data is based on the maximum likelihood algorithm of Minster \& Jordan (1978) and fitting functions of Chase (1978), modified to incorporate the ability to use geodetic vectors and their statistics.

First, we solved the Somalia-Nubia angular velocity in a two-plate inversion (Nubia-Somalia) using sites MALI, SEY 1 and REUN plus nine earthquake slip vectors along the Main Ethiopian Rift, a fairly simple single structure that marks the boundary between Nubia and Somalia between latitudes $5^{\circ} \mathrm{N}$ and $10^{\circ} \mathrm{N}$ (Fig. 1; Table 2). We repeated the inversion for Somalia-Nubia angular velocity without using earthquake slip vectors along the Main Ethiopian Rift and found a similar result. The associated 1-sigma confidence ellipse includes, although barely, previous GPS-derived SomaliaNubia estimates by Fernandes et al. (2004), Sella et al. (2002), and Prawirodirdjo \& Bock (2004). Differences between GPS estimates of plate motions may stem from the length of the time series used in the analysis, the version of the global reference frame used and its implementation, and the choice of sites used to define stable plates. Here, it is likely that the major difference is due to site REUN on the Somalian plate. For instance, Sella et al. (2002) and Prawirodirdjo \& Bock (2004) do not use REUN in their analysis. Sella et al. (2002) define Somalia using two sites only (SEY1 and MALI), to which Prawirodirdjo \& Bock (2004) add RBAY, even though that site is located on the Nubian side of the Nubia-Somalia plate boundary of Lemaux et al.'s (2002; Fig. 1). Fernandes et al. (2004) define Somalia using the same sites as our study but obtain a significantly different velocity at REUN (Fig. 1), rotated counter-clockwise compared to our solution. This shifts their Somalia-Nubia Euler pole south compared to ours. The reason for the velocity difference at REUN between the two solutions is unclear, as

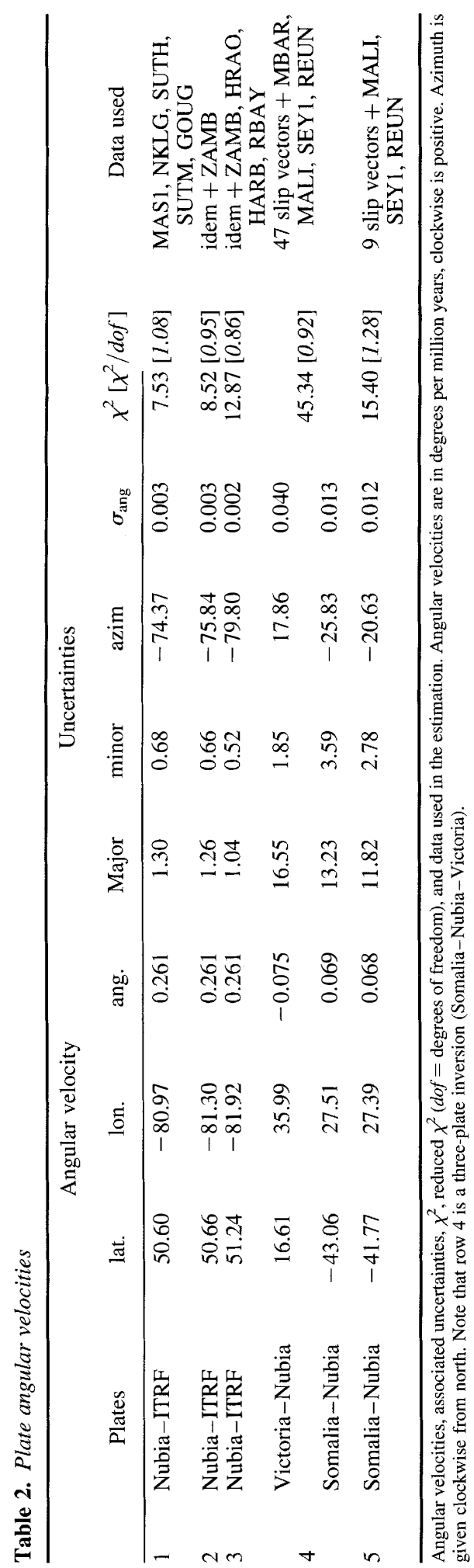




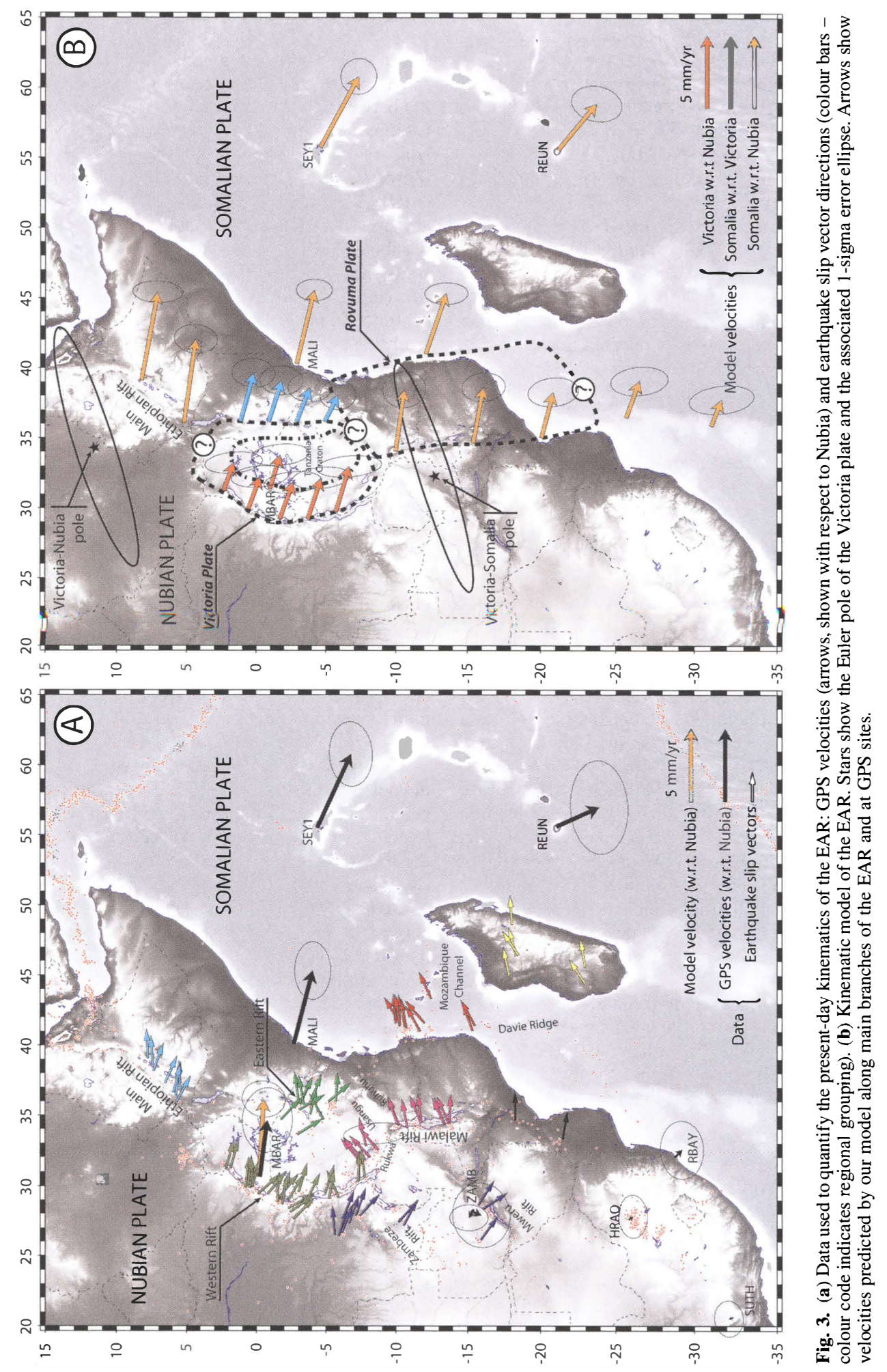


they agree better for other sites. It may be due to the shorter time series used by Fernandes et al. (2004), which stops in mid-2003, or to possible volcanic deformation. However, the five-year-long position time series at REUN shows a linear displacement over that time period (in spite of a data gap between mid-2000 and mid-2001; Fig. 2), with no clear indication of transient deformation due to volcanic processes.

The reason for a difference between our SomaliaNubia estimate and Chu \& Gordon's (1999) is less clear, but could reflect changes in the regional plate kinematics over the past $3 \mathrm{Ma}$ (Calais et al. 2003), a time of propagating plate boundaries in the Afar depression (e.g. Courtillot et al. 1999). Clearly, additional measurements at more sites on the Somalian plate (e.g. eastern Ethiopia, Somalia, Madagascar) are needed to firmly establish the present-day Somalia-Nubia motion.

We then compared the observed velocity at site MBAR with the one predicted by the SomaliaNubia angular velocity defined above (Fig. 3a). Site MBAR shows a significantly smaller magnitude than predicted and is rotated clockwise, in a direction close to earthquake slip vectors along the Western rift. This is consistent with the fact that MBAR is located on cratonic lithosphere within the Nubia-Somalia plate boundary zone, east of the Western rift. In addition, Figure 3a shows that earthquake slip vector directions are constant or vary smoothly along each of the major tectonic segments of the EAR (thin coloured arrows on Fig. 3a), as also observed by Foster $\&$ Jackson (1998), but are inconsistent with the predicted Nubia-Somalia plate motion direction along most of the EAR (thick orange arrows on Fig. 3b). These misfits between GPS velocities or earthquake slip vector directions and SomaliaNubia plate motion models indicate plate boundary zone deformation between Nubia and Somalia, in the form of continuously distributed strain or of rigid block motions.

Seismicity, active faulting and volcanism in the EAR are generally localized to the 50-80 km-wide Ethiopian rift, and the Western and Eastern rift valleys that bound the unfaulted and relatively aseismic Tanzania craton (Fig. 3). Seismic tomography models reveal a 200$250 \mathrm{~km}$-deep keel beneath this small Archaean craton (Ritsema et al. 1998). We discuss hereafter a possible microplate geometry, on the basis of seismotectonic data, and test this hypothesis by jointly inverting GPS and earthquake slip vector data for a three-plate kinematic model. We do not attempt to account for the belts of seismicity and faulting west of Lakes Rukwa and Nyasa (Malawi) (Fig. 3a), where the lack of data would make the analysis too speculative.

\section{Kinematics of the EAR}

The northernmost seismic belt of the EAR corresponds to the Main Ethiopian Rift, a single boundary between Nubia and Somalia (Fig. 3a). Near the Ethiopia-Sudan-Kenya border lies a complex zone of deformation where the EAR overprints Mesozoic to Palaeogene rifts (e.g. Hendrie et al. 1994). Seismicity is more diffuse and fault offsets are small in these poorly understood zones. South of about $3^{\circ} \mathrm{N}$, teleseismic and tectonic activity splits into two branches, the Eastern and Western rifts (Fig. 3). Most of the teleseismic activity is concentrated in the Western rift, which contains a relatively small volume of volcanic material (e.g. Foster \& Jackson 1998). On the contrary, the Eastern rift has eruptive centres along its length and moderate seismic activity, except near its southern termination at the edge of the Tanzania craton (e.g. Nyblade \& Langston 1995; Foster \& Jackson 1998). The Western rift wraps around the Archean Tanzania craton and connects southward with the Malawi rift via the reactivated Mesozoic Rukwa rift. Seismicity and field evidence for active deformation along the Malawi rift end between $20^{\circ} \mathrm{S}$ and $25^{\circ} \mathrm{S}$ (Fig. 3). Other seismic belts include a narrow, north-south trending zone of seismicity along the Davie Ridge in the Mozambique channel (Grimison \& Chen 1988) and the NE-SW trending Mweru and Zambezi rifts on both sides of the Early Proterozoic Zambia (Bangweulu) block.

These seismic belts bound broad areas mostly devoid of seismic activity. A northern block, centred on the Tanzania Archaean craton and bounded by the western and eastern branches of the EAR, has been referred to as the Victoria (Kaz'min et al. 1987) or Ukerewe-Nyanza (Hartnady 2002; Hartnady \& Mlisa 2004) block (Fig. 3b). A southern block, bounded to the west by the Malawi rift and to the east by the Davie Ridge, has been previously identified as the Rovuma block (Hartnady 2002). The eastern boundary of this block may encompass parts of Madagascar, where earthquake slip vectors have a similar direction as along the Davie Ridge (Fig. 3a). The boundary between the Victoria and Rovuma blocks is less clear as it is not well expressed in the seismicity or by recent faulting. Localized deformation occurs in the Usangu and Ruhuhu grabens (Fig. 3a), where seismic reflection, field, gravity and remote sensing data indicate recent extension along morphologically young normal faults that connect further north with the Eastern rift (Harper et al. 1999; Le Gall et al. 2004).

We estimate angular velocities for Somalia and Victoria with respect to Nubia by simultaneously inverting GPS velocities at sites MBAR (Victoria 
block) and REUN, SEY1 and MALI (Somalian plate) with earthquake slip vectors along the Main Ethiopian Rift (Somalia-Nubia boundary), the Western rift (Victoria-Nubia boundary) and the Eastern rift (Victoria-Somalia boundary). We use a $20^{\circ}$ standard deviation for earthquake slip vector directions, the $2 \sigma$ standard deviation for GPS velocities, and impose plate circuit closure in the inversion. Results are given in Table 2 and shown on Figures 1 and 3B. The reduced $\chi^{2}$ is close to unity, meaning that a three-plate model is consistent with the data within their uncertainties. We find a Somalia-Nubia velocity statistically similar to the two-plate inversion above, which is expected because no additional data are used to define the Somalian plate motion. We find that the kinematics of the Victoria block can be described by a counter-clockwise rotation with respect to Nubia about a pole located in NE Sudan (Fig. 3b). Equivalently, its kinematics with respect to Somalia can be described by a counter-clockwise rotation about a pole located in northern Zambia (Fig. 3b).

Figure $3 \mathrm{~b}$ shows the extension direction and rate predicted by our model along the eastern and western branches of the EAR, which we assumed to represent the boundaries of the Victoria microplate. We find that 2 to $5 \mathrm{~mm} \mathrm{a}^{-1}$, or 40 to $100 \%$ of the total Somalia-Nubia plate motion, is accommodated by extension across the Western rift, with present-day rates increasing from north to south. Our model predicts oblique extension in the Albert rift at the northern end of the Western rift, consistent with seismic reflection data showing a significant strike-slip component (Abeinomugisha \& Mugisha 2004). Conversely, 3.5 to $1 \mathrm{~mm} \mathrm{a}^{-1}$, or 60 to $20 \%$ of the total Somalia-Nubia plate motion, is accommodated by extension across the Eastern rift, with rates decreasing from north to south. This southward decrease of the extension rate is consistent with the decrease in seismicity and with the progressive disappearance of prominent active faults southward along the eastern branch, as it propagates into cold cratonic domain (Le Gall et al. 2004).

The kinematics of the Rovuma block cannot be fully quantified because there are no GPS data to estimate its rotation rate. However, earthquake slip vector directions and aligned chains of Quaternary eruptive centres along the Malawi rift (Rovuma-Nubia boundary) and the Davie ridge, the assumed Rovuma-Somalia boundary, provide some first-order constraints. ENE-directed slip vectors along the Malawi rift provide the direction of motion of the Rovuma block with respect to Nubia along the western border of the Rovuma block (Fig. 4b; Brazier et al.; Ebinger et al. 1989). A velocity triangle for a point on its eastern border (around $42^{\circ} \mathrm{W} / 12^{\circ} \mathrm{S}$, Fig. 4a) can be drawn using the Somalia-Nubia velocity, known from GPS data (see above), and the azimuth of the Somalia-Rovuma motion, given by the average slip vector direction on the Davie Ridge. Given that the magnitude of the latter vector is not known, the Rovuma-Nubia vector can be anywhere between $\mathrm{N} 95^{\circ} \mathrm{W}$ if the Somalia-Rovuma motion is close to zero (i.e. $100 \%$ of the Somalia-Nubia motion is taken up in the Malawi rift), to $\mathrm{N} 170^{\circ} \mathrm{W}$ if the SomaliaRovuma motion is close to Somalia-Nubia in magnitude (i.e. $100 \%$ of the Somalia-Nubia motion is taken up on the eastern boundary of the Rovuma plate). According to earthquake magnitudes from the 30-year global NEIC catalogue, seismic strain release has been larger at the Malawi rift than along the Davie Ridge, suggesting larger displacement rates on the western boundary of the Rovuma plate than on its eastern boundary. If this is representative of longer-term strain, then the Rovuma-Nubia velocity along the Davie Ridge is closer to east-west than north-south. In any case, the Rovuma-Nubia plate motion vector at the eastern boundary of the Rovuma plate around $42^{\circ} \mathrm{W} / 12^{\circ} \mathrm{S}$ must be pointing in a southeast quadrant (Fig. 4). This, together with the ENEdirected slip vectors along the western boundary of that plate (Malawi rift), implies a clockwise rotation of Rovuma with respect to Nubia.

Given the lack of significant active deformation features at the boundary between the Victoria and Rovuma plates, could the data used here be fit equally well with a single plate encompassing Victoria and Rovuma? The $c .45^{\circ}$ systematic difference in earthquake slip vector directions along the Western and Malawi branches (Fig. 3a) argues for two distinct plates. This can be further quantified by testing whether slip vectors along the Malawi rift are consistent with a single plate model. Including the Malawi rift slip vectors in a Nubia-[Victoria+Rovuma]-Somalia inversion gives a $\chi^{2}$ of 63.9 for 14 additional degrees of freedom (14 additional slip vector data). Using values from Table 2 (row 4), this leads to an $F$-test value of 1.3 , corresponding to $\alpha=0.77$. Hence, the hypothesis that the data fit equally well a single Victoria + Rovuma plate can be rejected at a $77 \%$ confidence level. This confidence level increases as a priori uncertainties on slip vector directions are lowered (we used $20^{\circ}$ here). The counter-clockwise rotation of Victoria and clockwise rotation of Rovuma (with respect to Nubia) found here may actually explain the lack of well-expressed active faults and seismicity along their common boundary, as schematically shown on Fig. 5. 

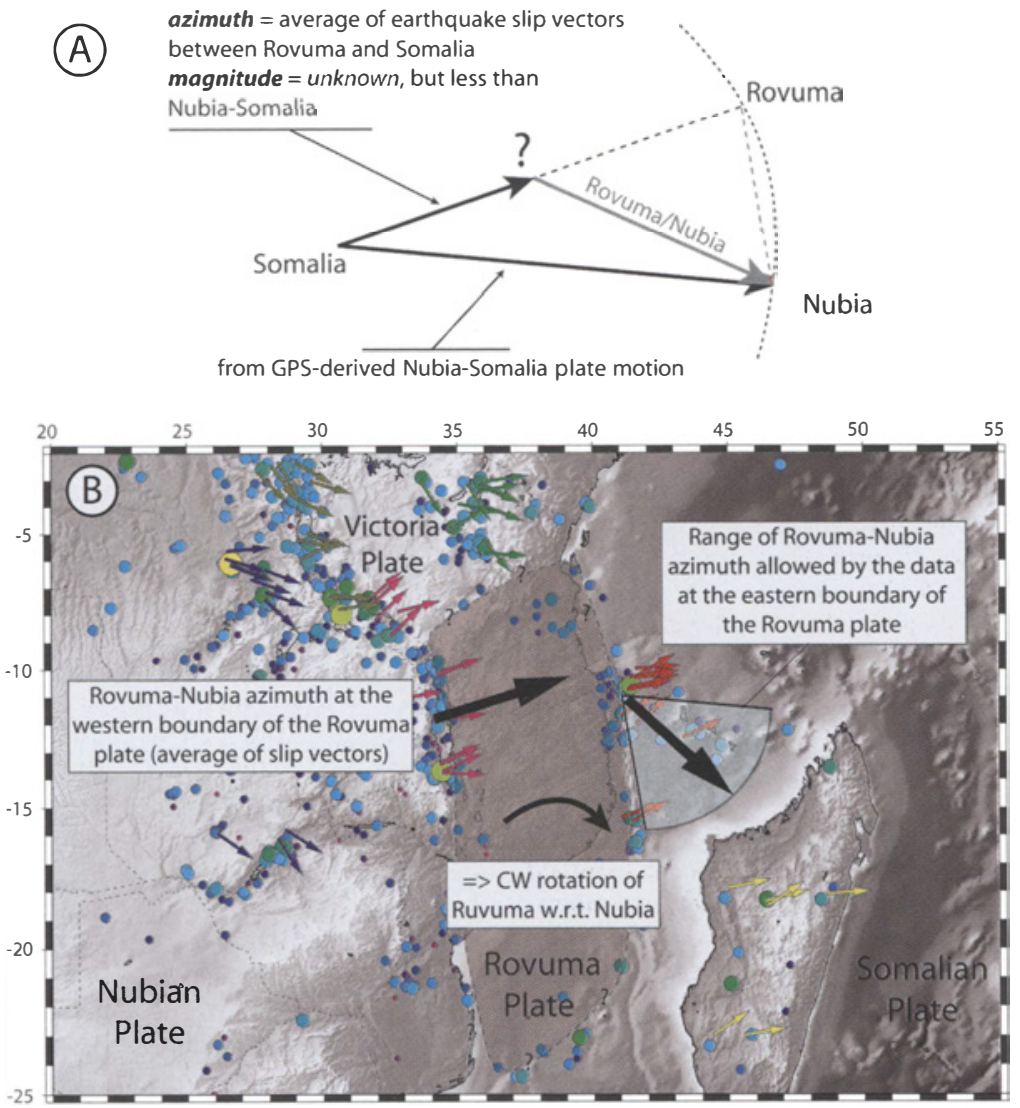

Fig. 4. Kinematics of the Rovuma block. (a) Velocity triangle for a location on the Rovuma-Somalia boundary around $42^{\circ} \mathrm{N} / 12^{\circ} \mathrm{S}$. (b) Zoom on the Rovuma plate. Large arrows show relative plate motions along its western and eastern boundaries (Malawi rift and Davie Ridge, respectively). They imply a CW rotation of Rovuma with respect to Nubia. Coloured arrows show earthquake slip vectors. Seismicity (NEIC catalog) is shown in background.

\section{Discussion and conclusion}

The kinematic model proposed here, although consistent with the existing data, does not account for the widespread seismicity observed west of the Western rift (Fig. 1), where earthquake slip vectors show a consistent NW-SE trend. This seismicity has been interpreted as delineating an additional microplate (Transgariep block of Hartnady 2002). However, GPS station ZAMB, located on that potential microplate, does not show any significant relative motion with respect to Nubia. In addition, active tectonic features along the Zambia and Mweru rifts (Fig. 2a) have a limited length and do not delineate a continuous plate boundary. These observations do not preclude a relative motion of the Zambian craton with respect to Nubia, but it must happen at very slow rates, less than $1-2 \mathrm{~mm} \mathrm{a}^{-1}$.
Extrapolating the instantaneous kinematics found here to finite amounts of extension across the EAR is difficult given that extension rates may have varied in time. Assuming constant rates since the initiation of rifting (from $12-15 \mathrm{Ma}$ to $\sim 8 \mathrm{Ma}$ from north to south along the Western rift and less than $5 \mathrm{Ma}$ for the Eastern rift; Ebinger et al. 1997; Ebinger 1989; Abeinomugisha \& Mugisha, 2004), the values found here lead to a maximum finite extension of about $30 \mathrm{~km}$ for the Western rift and 15 to $0 \mathrm{~km}$ (from north to south) for the Eastern rift. These values are at least twice the $15 \mathrm{~km}$ cumulative extension derived from reconstructions of surface fault geometries (Morley 1988; Ebinger 1989) and cantilever models of gravity and topography (Karner et al. 2000). The difference might be indicative of slower extension rates during the earlier phase of rifting. 


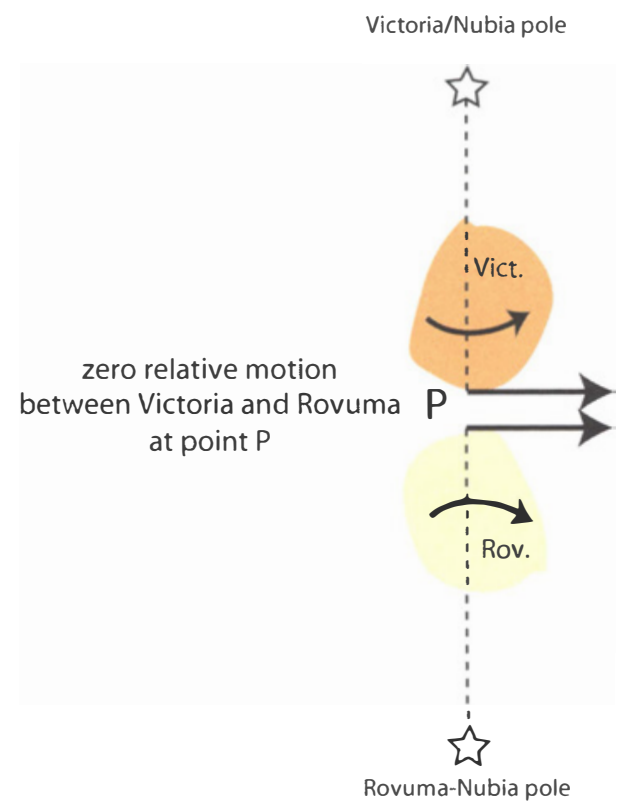

Fig. 5. Schematic kinematic diagram showing the counter-clockwise rotation of Victoria and clockwise rotation of Rovuma (with respect to Nubia). In the configuration shown here, the relative motion at point $P$ along their common boundary is null.

The GPS dataset used here is clearly limited, but it correlates well with earthquake slip vectors. The combined interpretation of the two data sets is consistent with a plate boundary model where deformation of the African plate is restricted to the narrow rift valleys, and the surrounding lithospheric blocks remain undeformed. These kinematic data are consistent with tomographic models that also show lithospheric thinning and heating restricted to $100-150 \mathrm{~km}$-wide zones beneath the faulted Ethiopian and Eastern rift valleys (e.g. Green et al. 1991; Ritsema et al. 1998; Bastow et al. 2005).

The identification of rigid lithospheric blocks that are kinematically independent from the Nubian or Somalian plates raises the question of the mechanism that drives their motion. The Ethiopian and Eastern rift systems form a diachronous but nearly contiguous belt that passes along the eastern side of the Tanzania craton. But what drives extension in the magma-poor Western rift system? A possible model stemming from studies of interactions between the cratonic keel and mantle flow provides insights into this problems. The core of the Victoria microplate is the 2.5-3 Ga Tanzania craton (Fig. 3b; Cahen et al. 1984), an assemblage of metamorphic and granitic terranes that has remained undisturbed tectonically since the Archaean, except for minor reheating attested by Tertiary kimberlites (e.g., Chesley et al. 1999). Seismic, xenolith and gravity data show that the lithosphere of the Tanzanian craton is colder and stronger than surrounding orogenic belts (e.g. Ebinger et al. 1997; Ritsema et al. 1998), and is underlain by a $170-250 \mathrm{~km}$-thick lithospheric keel (Nyblade et al. 2000; Weeraratne et al. 2003; Debayle et al. 2005).

Viscous coupling between the convecting mantle and the lithosphere has been proposed as a significant driving force (either active or resistive) for plate motions, in particular in cratonic domains where a deep lithospheric keel is embedded in the convecting mantle (e.g. Ziegler 1992; Bokelmann 2002; Fouch et al. 2002; Sleep et al. 2002). Fouch et al.'s models (2002) predict focusing of flow around the boundaries of the keel which match anisotropy patterns determined in SKS-splitting observations from North America. Sleep et al. (2002) followed with the case of a mantle upwelling and a cratonic keel, demonstrating the strong focusing effect and directionality in both decompression melting and anisotropy. But without a consensus on the present location of plume stem(s) (e.g. Weeraratne et al. 2003; Furman et al. this volume Rogers, this volume), we cannot easily compare models and observations (e.g. Walker et al. 2004; Kendall et al. this volume).

Seismic anisotropy measurements and azimuthal variations in surface wave models provide independent constraints on upper mantle flow beneath East Africa and its possible interaction with the Tanzania craton (Fig. 6; Kendall et al. this volume; Gao et al. 1997; Walker et al. 2004). Local, surface wave, and SKS-splitting measurements along the Ethiopian and Eastern rifts show that strong, rift-parallel, anisotropy is primarily due to aligned melt zones in the mantle lithosphere (Kendall et al. 2005; Kendall et al. this volume). Azimuthal variations in surface wave models show sub-lithospheric fast shear waves coherently oriented in a NE direction from Tanzania to the Red Sea (Debayle et al. 2005) and near-radial orientations from a possible plume stem beneath Lake Eyasi (Weeraratne et al. 2003). Overall, seismic anisotropy fast directions in east Africa parallel the trend of the deep African superplume, but not the WNW motion of the African plate in a hot-spot frame (Fig. 6). At a larger scale, Behn et al. (2004) explain SKS splitting observations on islands surrounding Africa with density-driven upwelling flow from the African superplume and its interactions with a moving plate. Thus, existing data show both a strong signal from asthenosphere and mantle lithosphere, as well as regional variations in flow direction around the margins of the deep-rooted Tanzania craton. 


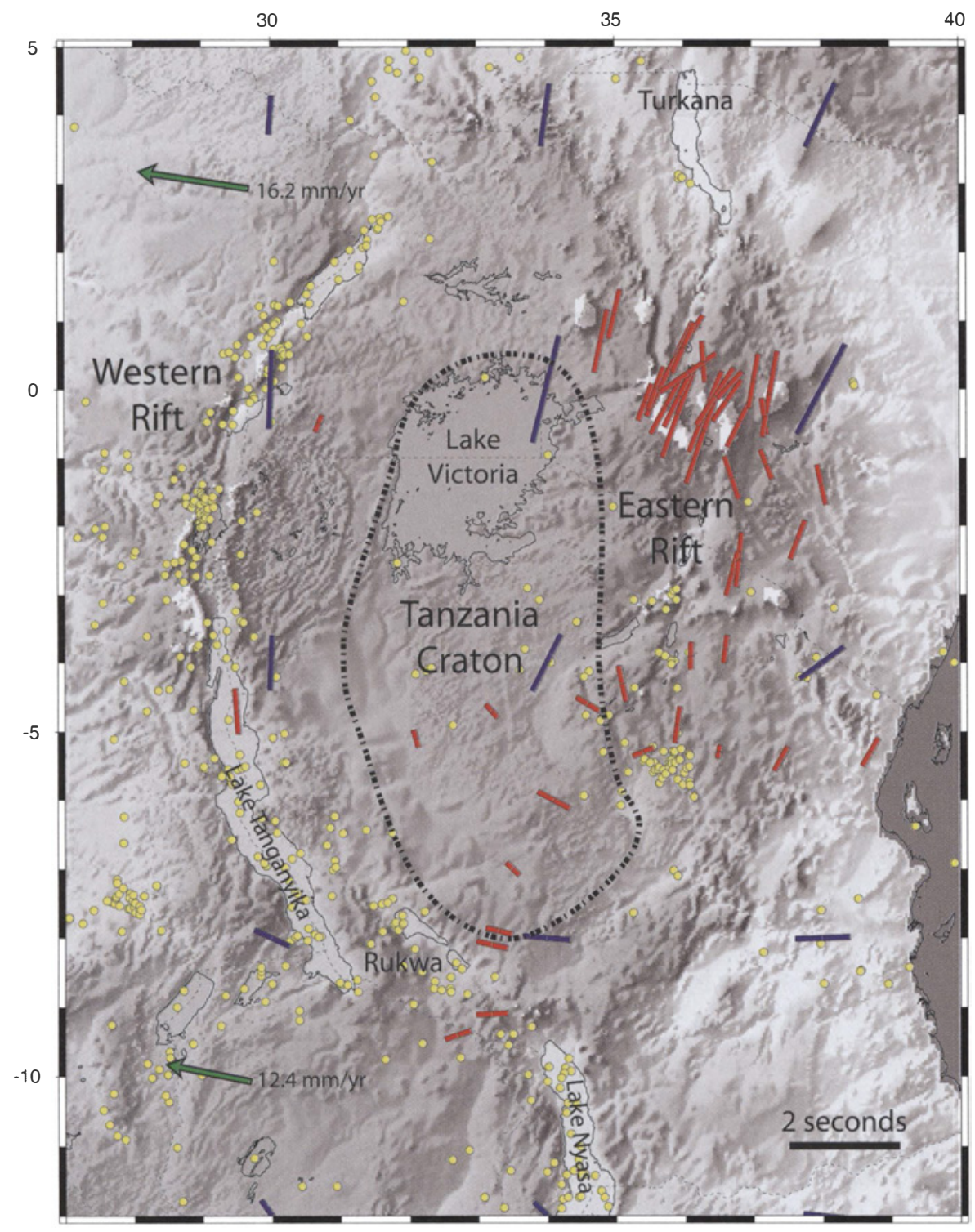

Fig. 6. Existing anisotropy data in the central part of the EAR. Red bars are from SKS shear-wave splitting data (Gao et al. 1997; Walker et al. 2004; Barruol \& Ismail 2001), blue bars are from a surface wave study for a depth of $200 \mathrm{~km}$ (Debayle et al., 2005). Green arrows show the current African plate motion in a hot-spot frame (Gripp \& Gordon 2002).

On the basis of the asthenosphere-lithosphere flow models and anisotropy analyses, we propose that the independent motion of the Victoria plate shown in this study results from a combination of along-axis mantle flow and increased drag exerted on the Tanzania craton lithospheric keel by viscous coupling with normal or enhanced asthenospheric flow (e.g. Stoddard \& Abbott 1996; Sleep et al. 2002; Fig. 7).

The NE-directed sublithospheric flow driven by the African Superplume upwelling acting on the Tanzanian craton keel, thickest in its southern part (Debayle et al. 2005), may force a counterclockwise rotation of the craton, consistent with 


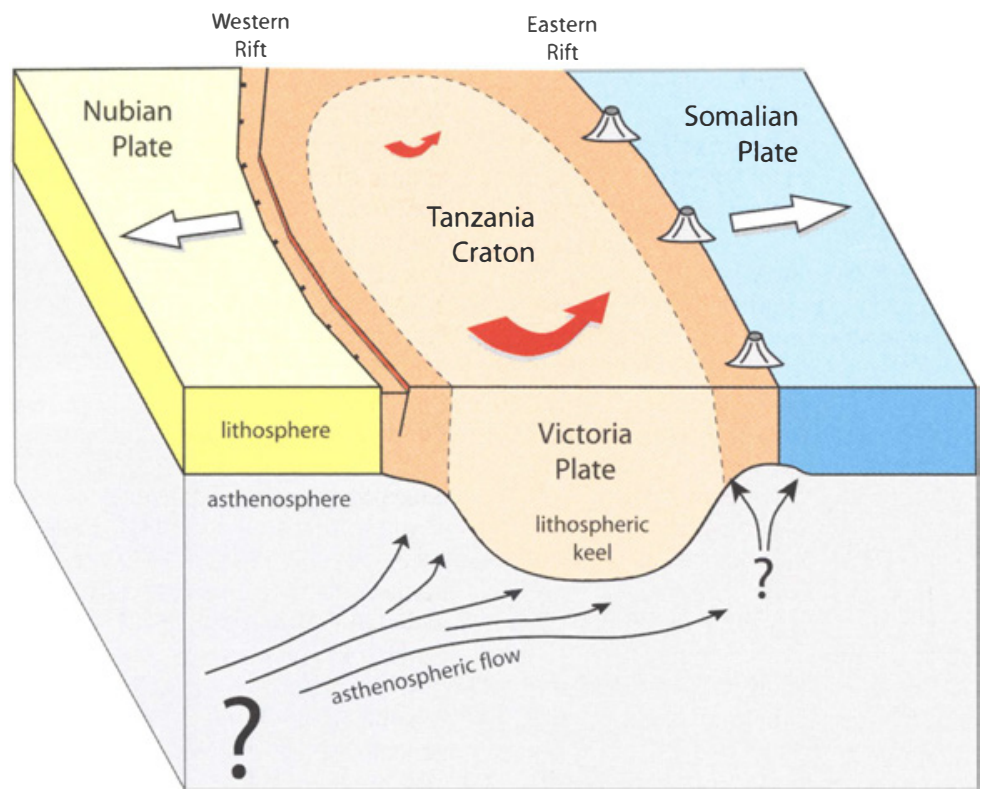

Fig. 7. Interpretative block diagram across the central part of the EAR. Viscous coupling between NE-directed asthenospheric flow driven by the African Superplume and the Tanzanian craton keel may force a counter-clockwise rotation of the craton, consistent with our preliminary kinematic data. The magma-poor Western rift accommodates differential movement of the deep-keeled Victoria plate, whereas the magma-rich Eastern rift formed in response to focused mantle flow with hot asthenosphere possibly ponding below thinned lithosphere.

our preliminary kinematic data. If confirmed, this differential rotation of the Victoria microplate can explain the origin and geometry of the enigmatic Western rift system without requiring a complex mechanism of stress transfer from the Eastern rift (Nyblade \& Brazier 2002). In this model, the magma-poor Western rift accommodates differential movement of the deep-keeled Victoria plate, whereas the magma-rich Eastern rift formed in response to focused mantle flow with hot asthenosphere possibly ponding below thinned lithosphere. The interaction between southward-deepening asthenospheric upwelling may also explain the seismicity belts with minor or incipient normal faults that bound cratonic domains in southern Africa (Kaapvaal, Zimbabwe, Zambia cratons). With increased GPS and seismic coverage of the African continent, we should be able to map these variations in deformation and mantle flow and build a database to test current models for the fragmentation of continental plates in response to plate-driving forces.

This paper results in large part from discussions held during the US-Africa Workshop on Anatomy of Continental Rifts in Addis Ababa, Ethiopia, in June 2004. We are grateful to the local organizing committee and to
M. Abdelselam, S. Klemperer and Gezahegn Yirgu for making this event possible. We thank M. Kendall, B. Le Gall, J. Rolet, J. Déverchère and W. Vétel for insightful discussions on the East African Rift, R. Gordon for reviewing an early version of this manuscript, and C. Vigny and Z. Garfunkel for their constructive comments.

\section{References}

Abeinomugisha, D. \& Mugisha, F. 2004. Structural analysis of the Albertine graben, Western Uganda. Abstract, East African Rift System Evolution, Resources, and Environment Conference, Addis Ababa, June.

Altamimi, Z., Sillard, P. \& Boucher, C. 2002. ITRF2000: A new release of the International Terrestrial Reference Frame for earth science applications. Journal of Geophysical Research, 10.1029/2001 JB000561.

Barruol, G. \& Ben-IsMaIL, W. 2001. Upper mantle anisotropy beneath the African IRIS and GEOSCOPE stations. Geophysical Journal International, 146, 549-561.

Bastow, I., Stuart, G.W., Kendall, J.M. \& EBINGER, C. 2005. Upper mantle seismic structure in a region of incipient continental breakup: northern Ethiopian rift. Geophysical Journal International, 162, 479-493 doi: 10.111/j.1365-246X. 2005.02666.x. 
Behn, M.D., Conrad, C.P. \& Silver, P.G. 2004. Detection of upper mantle flow associated with the African Superplume. Earth and Planetary Science Letters, 224, 259-274.

Bokelmann, G. 2002. Convection-driven motion of the North American craton: evidence from P-wave anisotropy. Geophysical Journal International, 148, 278-287.

Brazier, R.A., Nyblade, A.A. \& Florentin, J. 2005. Focal mechanisms and the stress regime in NE and SW Tanzania, East Africa. Geophysical Research Letters, 32, L14315, doi: 10.1029/2005 GL023156.

Cahen, L., Snelling, N.J., Delhal, J. \& Vail, J.R. 1984. The Geochronology and Evolution of Africa. 512 pp., Oxford University Press, New York.

Calais, E., DeMets, C. \& Nocquet, J.M. 2003. Evidence for a post-3.16 Ma change in NubiaEurasia plate motion. Earth and Planetary Science Letters, doi:10.1016/S0012821X(03)00482-5.

Chase, C.G. 1978. Plate kinematics: the Americas, East Africa, and the rest of the world. Earth and Planetary Science Letters 37, 353-368.

Chesley, J.T., Rudnick, R.L. \& Lee, C.T. 1999. $\mathrm{Re}-\mathrm{Os}$ systematics of mantle xenoliths from the East African rift: Age, structure, and history of the Tanzanian craton. Geochimica and Cosmochimica Acta, 63, 1203-127.

CHu, D. \& GoRdon, R. 1999. Evidence for motion between Nubia and Somalia along the Southwest Indian ridge. Nature, 398, 64-66.

Courtillot, V., Manighetti, I., TApponnier, P. \& Besse, J. 1999. On causal links between flood basalts and continental breakup. Earth and Planetary Science Letters, 166, 177-195.

Debayle, E., Kennett, B. \& Priestley, K. 2005. Global azimuthal seismic anisotropy and the unique plate-motion deformation of Australia. Nature, 433, 509-512, doi:10.1038/nature03247.

EBINGER, C. 1989. Tectonic development of the western branch of the East African Rift System. Bulletin of the Geological Society of America, 101, 885-903.

Ebinger, C., Poudjom-Djomani, Y., Mbede, E. \& Foster, A. 1997. Rifting the Archaean: Development of the Natron-Manyara-Eyasi basins. Tanzania, Journal of the Geological Society London, 154, 947-960.

Ebinger, C., Bechtel. T., Forsyth, D. \& Bowin, C. 1989. Effective elastic plate thickness beneath the East African and Afar plateaux, and dynamic compensation of the uplifts. Journal of Geophysical Research, 94, 2883-2901.

Fernandes, R.M.S, Ambrosius, B.A.C., Noomen, R., Bastos, L., Combrinck, L., Miranda, J.M. \& SPAKMAN, W. 2004. Angular velocities of Nubia and Somalia from continuous GPS data: implications on present-day relative kinematics. Earth and Planetary Science Letters, 222, 197-208.

Foster, A. \& JACKSON, J.A. 1998. Source parameters of large African earthquakes: implications for crustal rheology and regional kinematics. Geophysical Journal International, 134, 422-448.

Fouch, M., Fischer, K.M., Parmentier, E.M., Wysession, M.E. \& Clarke, T.J. 2000. Shearwavesplitting, continental keels and patterns of mantle flow. Journal of Geophysical Research, 105, 6255-6275.

Furman, T., Bryce, J., RoOney, T., Hanan, B., Yirgu, G. \& Ayalew, D. 2006. Heads and Tails: 30 Million years of the Afar plume. In: YIRGU, G., Ebinger, C.J. \& Maguire, P.K.H. (eds) The Afar Volcanic Province within the East African Rift System. Geological Society, London, Special Publications, 259, 95-119.

GAO, S., Davis, P.M., ET AL. 1997. SKS splitting beneath continental rift zones. Journal of Geophysical Research, 102, 22781-22797.

Gordon, R. G. 1998. The plate tectonic approximation: Plate nonrigidity, diffuse plate boundaries, and global plate reconstructions. Annual Reviews of Earth and Planetary Sciences, 26, 615-642.

Green, V., Achauer, U. \& Meyer, R.P. 1991. A 3D seismic image of the crust and upper mantle beneath the Kenya rift. Nature, 354, 199-203.

Grimison, N.L. \& ChEN, W.P. 1988. Earthquakes in Davie Ridge-Madagascar region and the southern Nubian-Somalian plate boundary. Journal of Geophysical Research, 93, 10,439-10,450.

GRIPP, A.E. \& GoRDON, R.G. 2002. Young tracks of hotspots and current plate velocities. Geophysical Journal International, 150, 321-361.

Harper, R., Stone, D. \& Morley, C.K. 1999. Geophysics of the Usangu flats, Tanzania. In: MORley, C.K. (ed.) Geoscience of Rift Systems - Evolution of East Africa, AAPG Studies in Geology, No. 44, 111-114.

HARTNADY, C.J.H. 1998. Lesotho seismotectonics: SE African SCR in transition. American Geophysical Union Chapman Conference on Stable Continental Region (SCR) Earthquakes, National Geophysical Research Institute, Hyderabad, India (January 25-29), Abstract Volume, p. 23.

HARTNADY, C.J.H. 2002. Earthquake hazard in Africa: perspectives on the Nubia-Somalia boundary. South African Journal of Sciences, 98, 425-428.

Hartnady, C.J.H. \& MlisA, A. 2004. Boundaries and recent motions of the Ukerewe-Nyanza plate. International Conference on the East African Rift System: Development, Evolution and Resources, Addis Ababa (June 20-24), Ethiopia, 81-84.

Hendrie, D., Kusznir, N., Morley, C.K. \& EBINGER, C.J. 1994. A quantitative model of rift basin development in the northern Kenya rift: Evidence for the Turkana region as an 'accommodation zone' during the Paleogene. Tectonophysics, 236, 409-438.

JACKSON, J.A. 2002. Strength of the continental lithosphere: time to abandon the jelly sandwich? GSA Today, September issue.

Jestin, F., Huchon, P. \& Gaulier, J.M. 1994. The Somali plate and the East African Rift system: present-day kinematics. Geophysical Journal of International, 116, 637-654. 
Karner, G., Byamungu, B., Ebinger, C., Kampunzu, A., Mukasa, R., NyakaAna, J., Rubondo, E. \& UpCoTt, N. 2000. Distribution of crustal extension and regional basin architecture of the Albertine rift system, East Africa. Marine and Petroleum Geology, 17, 1131-1150.

KaZ'Min, V.G., Zonenshayn, L.P., SAvostin, L.A. \& BershbitskayA, A.I. 1987. Kinematics of the Afro-Arabian rift system. Geotectonics, 21, $452-460$.

Kendall, J.-M., Stuart, G.W., Ebinger, C.J., BAstow, I.D. \& KEIR, D. 2005. Magma-assisted rifting in Ethiopia. Nature, 433, 146-148.

Kendall, J-M., Pilidou, S., Keir, D., Bastow, I.D., Stuart, G.W. \& Ayele, A. 2006. Mantle upwellings, melt migration and the rifting of Africa: Insights from seismic anisotropy. In: YIRGU, G., Ebinger, C.J. \& Maguire, P.K.H. (eds) The Afar Volcanic Province within the East African Rift System. Geological Society, London, Special Publications, 259, 55-72.

KING, R.W. \& Bock, Y. 2005. Documentation for the GAMIT GPS software analysis, release 10.2. unpublished.

Le Gall, B., Gernigon, L., ET AL. 2004. NeogeneRecent rift propagation in Central Tanzania: Morphostructural and aeromagnetic evidence from the Kilombero area. Bulletin of the Geological Society of America, 116, 490-510.

Lemaux, J., Gordon, R.G. \& Royer, J.-Y.2002. The location of the Nubia-Somalia boundary along the Southwest Indian Ridge. Geology, 30, 339-342.

McKenzie, D.P., Davies, D. \& Molnar, P. 1970. Plate tectonics of the Red Sea and East Africa. Nature, 226, 243-248.

MinsteR, J.B. \& JoRdan, T.H. 1978. Present-day plate motions. Journal of Geophysical Research, 83, $5331-5354$.

Modisı, M.P., Atekwana, E.A., Kampunzu, A.B. \& NGWISANYI, T.H. 2000. Rift kinematics during the incipient stages of continental extension: Evidence from the nascent Okavango rift basin, northwest Botswana. Geology, 28, 939-942.

Morley, C. K. 1988. Variable extension in Lake Tanganyika. Tectonics, 7, 785-801.

Nyblade, A.A. \& Langston, C.A. 1995. East African earthquakes below $20 \mathrm{~km}$ depth and their implications for crustal structure. Geophysical Journal of International, 121, 49-62.

Nyblade, A. \& BRAZIER, R. 2002. Precambrian lithospheric controls on the development of the East African rift system. Geology, 30, 755-758.
Nyblade, A.A., Owens, T.J., Gurrola, H., Ritsema, J. \& Langston, C.A. 2000. Seismic evidence for a deep upper mantle thermal anomaly beneath East Africa. Geology, 7, 599-602.

PRAWIRODIRDJO, L. \& BocK, Y. 2004. Instantaneous global plate motion model from 12 years of continuous GPS observations. Journal of Geophysical Research, 109, B08405, doi:10.1029/ 2003JB002944.

Ritsema, J., Nyblade, A.A., Owens, T.J. \& LangSTON, C.A. 1998. Upper mantle seismic velocity structure beneath Tanzania, east Africa: Implications for the stability of cratonic lithosphere. Journal of Geophysical Research, 103, 21, $201-21,213$.

Rogers, N.W. 2006. Basaltic magmatism and geodynamics of the East African Rift System. In: Yirgu, G., Ebinger, C.J. \& Maguire, P.K.H. (eds) The Afar Volcanic Province within the East African Rift System. Geological Society, London, Special Publications, 259, 77-93.

Sella, G. F., Dixon, T.H. \& MaO, A. 2002. REVEL: A model for recent plate velocities from Space Geodesy. Journal of Geophysical Research, doi: 107, 10.1029/2000JB00033.

Sleep, N.H., Ebinger, C.J. \& Kendall, J.M. 2002. Deflection of mantle plume by cratonic keels. In: Fowler, C.M.R., Ebinger, C.J. \& HawkeswORTH, C.J. (eds) The Early Earth: Physical, Chemical, and Biological Development. Geological Society, London, Special Publications, 199, $135-150$.

Stoddard, P.R. \& Аввотт, D. 1996. Influence of tectosphere upon plate motion. Journal of Geophysical Research, 101, 5425-5433.

Walker, K.T., Nyblade, A.A., Klemperer, S.L., BokelmanN, G.H.R. \& Owens, T.J. 2004. On the relationship between extension and anisotropy: Constraints from shear wave splitting across the East African Plateau. Journal of Geophysical Research, 109, B08302, doi: 10.1029/ 2003JB002866.

Weereratne, D.S., Forsyth, D.W., Fischer, K.M. \& Nyblade, A.A. 2003. Evidence for an upper mantle plume beneath the Tanzanian craton from Rayleigh wave tomography. Journal of Geophysical Research, 108, doi:10,1029/ 2002JB002273.

ZIEGLER, P. 1992. Plate tectonics, plate moving mechanisms and rifting. Tectonophysics, 215, 9-34. 